conventional method, whereas only 5 trips were necessary for the prebaiting method.

This savings in time accompanied by increased capture rates indicate the prebaited method is both more effective and efficient than convertional livetrapping techniques.

Acknowledgements: The author thanks Dr. Thomas P. Husband of the Department of Fisheries and Wildlife for his criticism, advice and encouragement throughout the study. This study was partially funded by a Grant-in-Aid of Research from Sigma Xi, The Scientific Research Society of North America.

\title{
REFERENCES
}

Ludwig J. \& Davis D. E., 1975: An improved woodchuck trap. J. Widl. Manage., 39: 439-443. N i x on C. M., M c Cla in M. W. \& D o n o ho e R. W., 1775: Effects of hunting and mast crops on a squirrel population. J. Wildl. Manage., 39: 1-25. Taber R. D. \& $\mathrm{C}$ ow a n I. McT., 1969: Capturing and marking vild animals. [In: R. H. Giles, Jr., ed. »Wildlife management techniques«], 3rd ed. The Wildlife Society: 277-317. Washington, D. C. O vert on W. S., 1969: Estimating the numbers of animals in wildlife populations. [In: R. H. Giles, Jr., ed. "Wildife management techniques«], 3rd ed. The Wildlife Society: 403-455. Washington, D. C. Z a r. J. M., 1974 Biostatistical analysis. Prentice-Hall: 1-622. Englewod Cliffs, New Jersey.

Accepted, November 2, 1976.

\section{Seasonal Cycles of Body Weight and Lipids in Richardson's Ground Squirrel, Spermophilus richardsonii elegans}

Sezonowe wahania ciężaru ciała i poziomu lipidów u Spermophilus richardioni

David A. ZEGERS ${ }^{1}$ \& Olwen WILLIAMS

Zegers D. A. \& Williams O., 1977: Seasonal cycles of body weight and lipids in Richardson's ground squirrel, Spermophilus richardsonii elegans. Acta theriol., 22, 29: $380-383$ [With 1 Table \& 1 Fig.].

Because of the significant linear correlation between body weight and lipid level, annual changes in body weight were related to a cycle in lipid for Spermophilus richardsonii elegans. Significant differences in mean weight between adult males and females were found both at emergence and immergence. Although lipid was not completelly depleted at emergence, both sexes exhibited sharp lipid losses immediately after emergence, which was probably due to increased energy expenditure during reproduction and to the minimal supply of food available at the beginning of the growing season.

[Dept. EPO Biol. Univ. Colorado, Boulder, Colorado 80309, USA]

The importance of biomass and lipid cycles in small mammals becones more apparent as energy flow studies become increasingly common. The significance of these cycles is especially obvious in hibernators vho,

1 Present address: Dept. Biol., Millersville State Coll., Millersville, Pa. 17551, USA. 
within a few weeks, must repost enough fat to sustain themselves through a long dormant period. Lipid cycles have been documented in several hibernating ground squirrels: Spermophilus beldingi (M or t o n, 1975), $S$. beecheyi (T o m i c h, 1962), and S. lateralis (J a m e s o n \& $\mathrm{M}$ e a d, 1964). N e a 1 (1965) found $S$. tereticaudus, a hibernator, gained weight and deposited lipid prior to hibernation in the laboratory, whereas $\mathrm{Am}$ mospermophilus harrisi, a non-hibernator, did not deposit fat when given abundant food in the laboratory.

The purpose of this paper is to delineate annual weight changes in Richardson's ground squirrel, Spermophilus richardsonii elegans K e n$\mathrm{nicott}$ (=S. elegans sensu $\mathrm{Nadler}, \mathrm{H}$ offmann \& Greer 1971) and to relate them to a lipid cycle.

As part of a study of energetics and behavior, adult ground squirrels were trapped on 16 occasions during the summers of 1975 and 1976 from a colony living in a montane meadow at an elevation of 2440 meters in Boulder County, Colorado. On capture, each individual was weighed to the nearest 5 grams, marked so as to be identifiable at a distance, and released. Mean weights, standard deviations, and sample sizes for adult males and adult females are shown in Table 1, while a plot of the mean

Table 1

Mean weights, standard deviations, and sample sizes for adult Richardson's ground squirrels trapped in a Colorado montane meadow during the summers of 1975 and 1976.

\begin{tabular}{|c|c|c|c|c|c|c|}
\hline \multirow{2}{*}{ Date } & \multicolumn{3}{|c|}{ Adult Males } & \multicolumn{3}{|c|}{ Adult Females } \\
\hline & Mean & SD & $\mathrm{N}$ & Mean & SD & $\mathrm{N}$ \\
\hline 20 May 75 & 319 & 27.87 & 8 & 306 & 24.99 & 10 \\
\hline 13 June & 307 & 11.55 & 3 & 283 & 26.46 & 9 \\
\hline 26 June & 337 & 51.32 & 3 & 311 & 35.42 & 10 \\
\hline 12 July & 387 & 30.11 & 6 & 342 & 18.32 & 8 \\
\hline 21 July & 465 & 21.21 & 2 & 337 & 30.55 & 3 \\
\hline 30 July & 470 & 24.49 & 4 & - & - & - \\
\hline 6 Aug & 460 & - & 1 & - & - & - \\
\hline $30 \mathrm{Mar} 76$ & 285 & 34.15 & 4 & 240 & - & 1 \\
\hline $6 \mathrm{Apr}$ & 270 & 30.00 & 3 & 208 & 33.71 & 6 \\
\hline $17 \mathrm{Apr}$ & 252 & 25.22 & 13 & 249 & 43.53 & 24 \\
\hline 4 May & 275 & 35.64 & 6 & 288 & 39.61 & 13 \\
\hline 14 May & 300 & 15.81 & $\mathbf{5}$ & 302 & 43.08 & 11 \\
\hline 19 May & 305 & 33.17 & 4 & 292 & 39.52 & 11 \\
\hline 26 May & 314 & 20.74 & 5 & 291 & 28.78 & 7 \\
\hline 2 June & 314 & 29.15 & 5 & 287 & 31.29 & 10 \\
\hline 10 June & 346 & 28.05 & 6 & 284 & 30.32 & 16 \\
\hline
\end{tabular}

weights is found in Figure 1. In addition, twelve adults from other parts of the colony were sacrificed. Stomach contents were removed and preserved, and the carcasses were dried and ground to a homogeneous mixture. Lipid was then extracted from this mixture using standard chemical techniques and a Labco Goldfisch Extraction Apparatus. The following values were calculated: a) grams dry lean weight, b) grams fat, and c) fat index (grams fat/grams lean dry weight). The linear relationship between live weight (W) and fat index (F. I.) was described by the equation, F. I. $=0.00696(W)-1.6797$ and was highly significant $(r=$ 
$=0.9018 ; \mathrm{n}=12 ; \mathrm{p}<0.001) . \mathrm{Clark}$ (1970a) showed that, in these ground squirrels, tail length, right hind foot length, and body length essentially stop increasing after 70 days of age; hence, weight differences among adult Richardson's ground squirrels are predominantly the result of differences in the quantity of lipid stored. The annual weight cycle, therefore, is a cycle in lipid level. As a result the right-hand

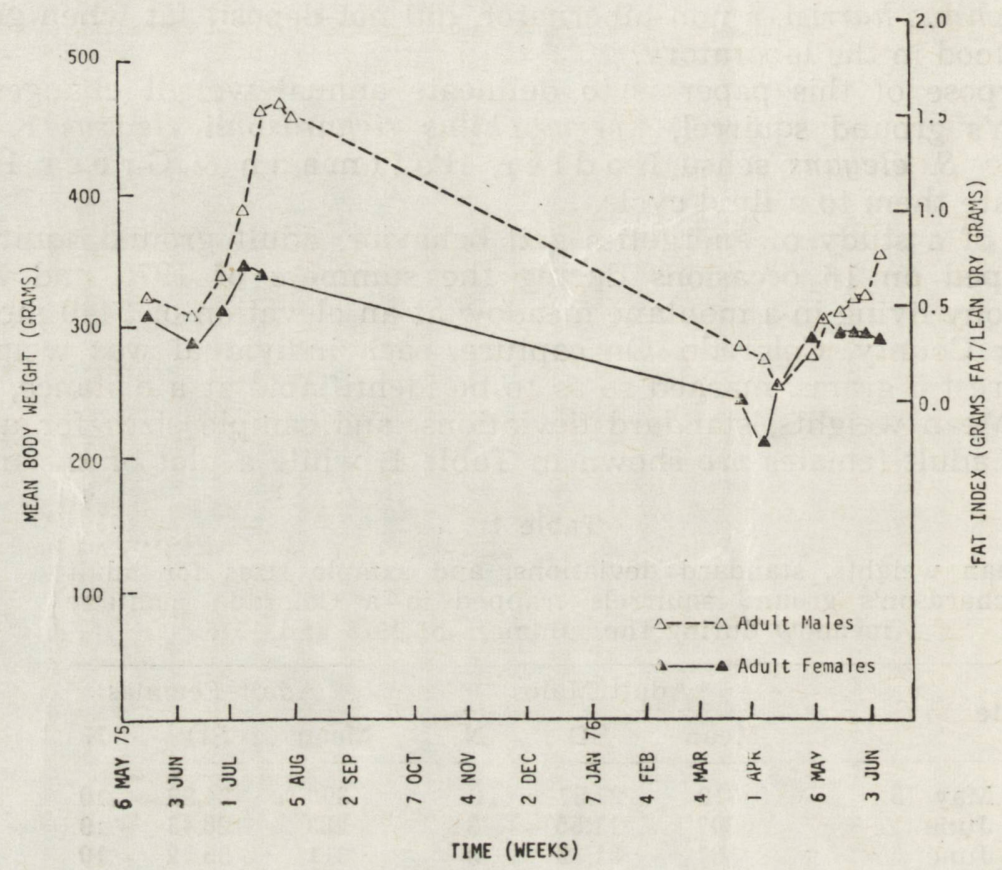

Fig. 1. Mean body weights for adult Richardson's ground squirrels caught fom a Colorado montane meadow from 20 May 1975 through 10 June 1976. The righthand $y$-axis indicates the corresponding fat index for any given weight.

$y$-axis in Figure 1 was placed to highlight the synchrony of lipid and weight changes. These changes closely agree with data on fat deposition presented by $\mathrm{Cla} \mathrm{rk}(1970 \mathrm{~b})$ and the weight cycle for $S$. r. richardsonii (M i c h e n e r, 1974).

Figure 1 shows a pronounced annual lipid cycle for adult males and a considerably less pronounced cycle for females. Both sexes exhibted sharp weight and lipid losses immediately after arousal in early April, probably as a result of reproductive activity and of food shortage during the early part of the season. Males then increased in weight until hikernation; females, however, did not gain as rapidly, probably because of increased energy expenditure during gestation and lactation. Interestinsly, the females disappeared (i.e. were not trapped nor observed) earlier in 1975 than the males, apparently going into hibernation before the males. Females weighed significantly less than males at immergence $(t=15.08$; $p<0.001$ for means of 470 and 337 grams) and after emergence 
$(t=13.60 ; p<0.001$ for means of 285 and 208). These weight differences do not appear to be important for over-winter survival; all females marked before immergence $(n=8)$ in 1975 were present after emergence the next spring, indicating either that females hibernated at lower metabolic rates than males or that all lipid stored by males was not nesessary for winter survival.

These results agree with the observations of other investigators. $\mathrm{Cl}$ a r k $(1970 \mathrm{~b})$ noted a depletion of depot fat subsequent to the emergence of $S$. richardsonii, and $\mathrm{H}$ ou se (1964) reported more rapid and greater weight gain in males than in females. $\mathrm{M}$ i c h e $\mathrm{n}$ er (1974), H o u s e (1964) and $\mathrm{Cla} \mathrm{rk}(1970 \mathrm{~b})$ all reported similar weight differences at immergence. $S$. beldingi, like $S$. richardsonii, appears to deposit much more lipid than needed. M o r t o n (1975) reported total body lipid at hibernation equalling or exceeding basic weight (i.e. fat index $\geq 1.0$ ) and lipid at emergence equalling 40 per cent of basic weight (i.e. fat index $=0.50$ ). Fat indices at emergence in the present study were also about 0.40 . Kleiber (1961) indicated terminal starvation at fat levels of $2.3 \%$ to $2.5 \%$ (i.e. fat indices of 0.10 to 0.12 ). These values suggest that neither $S$. beldingi nor $S$. richardsonii experience totally depleted lipid reserves at emergence. Nevertheless, data on the left abdominal fat depot in S. richardsonii (C la r k, 1970b) indicate near depletion of lipid occurs in April; the fat indices of April in Figure 1 similarly show near depletion of lipid for males and complete depletion for females. Therefore, the amount of energy stored as body lipid must not only bring the animal through hibernation, but it must also provide significant amounts of energy during the first month after emergence when reproduction is starting and when food supply is minimal.

Acknowledgments: We thank Nathaniel Stins on, Jr. and Dr. David A r m st rong for many helpful suggestions in reviewing the manuscript.

\section{REFERENCES}

C 1 a r k T.W., 1970a: Early growth, development, and behavior of the Richardson ground squirrel (Spermophilus richardsonii elegans). Amer. Midland Natur., 83: 197-205. Cla rk T. W., 1970b: Richardson's ground squirrel (Spermophilus richardsonii) in the Laramie Basin, Wyoming. Great Basin Natur., 30: 55-70. H o u s e W. A., 1964: Food habits of Richardson's ground squirrel in south-central Wyoming. M.S. Thesis. Colo. State Univ., Ft. Collins, Colo. J a m e s o n E. W., Jr., \& M e a d R. A., 1964: Seasonal changes in body fat, water and basic weight in Citellus lateralis, Eutamias speciosus, and E. amoenus. J. Mammal., 43: 359-365. K 1 e i b e r M., 1961: The fire of life: an introduction to animal energetics. Wiley: $1-454$. New York. Michener D. R., 1974: Annual cycle of activity and weight changes in Richardson's Ground Squirrel, Spermophilus richardsonii elegans. Can. FieldNatur., 88: 409-413. M o r t o n M. L., 1975: Seasonal cycles of body weight and lipids in Belding ground squirrels. Bull. Southern California Acad. Sci., 74: 128143. Nadler C. F. H of $\mathrm{fm}$ an $\mathrm{n}$. S. \& Greer K. R., 1971: Chromosomal divergence during evolution of ground squirrel populations (Rodentia: Spermophilus). Syst. Zool., 20: 298-305. N e a 1 B. J., 1965: Seasonal changes in body weights, fat depositions, adrenal glands and temperatures of Citellus tereticaudus and Citellus harrisii (R odentia). Southwestern Natur., 10, 3: 156-166. Tomich J. Q., 1962: The annual cycle of the California ground squirrel, Citellus beecheyi. Univ. California Publ. in Zool., 65: 213-282. 